FACTA UNIVERSITATIS

Series: Linguistics and Literature Vol. 16, $\mathrm{N}^{\mathrm{o}} 1,2018$, pp. 65-80

https://doi.org/10.22190/FULL1801065Z

Original Scientific Paper

\title{
INTERPRETING THE AT-ISSUE STATUS OF NON-RESTRICTIVE RELATIVE CLAUSES IN A FOREIGN LANGUAGE: A CASE OF SERBIAN EFL STUDENTS
}

\author{
UDC 811.111'367.3
}

\section{Ema Živković}

Faculty of Philosophy, University of Niš, Serbia

\begin{abstract}
Linguistic utterances can convey content which represents the speaker's main point and is considered to be at-issue, as well as secondary content which is interpreted as not-at-issue. A large number of diverse expressions which carry some kind of not-at-issue content have been identified. The present paper contributes to the ongoing investigation of one group of such expressions, non-restrictive relative clauses (NRRCs), in English as a foreign language. The starting point of the paper is an approach developed by Jasinskaja (2016), which accounts for at-issue status within the general theory of discourse interpretation. An important prediction that it makes is that final NRRCs connected with their main clauses via coordinating discourse relations should express more at-issue behavior than final NRRCs connected with their main clauses via subordinating discourse relations. Relying on this approach, the present paper aims to investigate the way Serbian EFL students interpret the at-issue status of NRRCs and to compare the results to the existing data in English (Živković 2016). The direct rejection test (Tonhauser 2012) was used to diagnose the at-issue status of the test items, which involved the manipulation of coordinating and subordinating discourse relations between main clauses and NRRCs. The overall results indicated that the percentage of rejections targeting coordinate NRRCs was significantly higher than the percentage of subordinate NRRC rejections. Comparing these results to the ones obtained in English showed that Serbian EFL students performed at the same level as native speakers of English when interpreting the at-issue status of English NRRCs.
\end{abstract}

Key words: (not-)at-issue status, non-restrictive relative clause, appositive relative clause, continuative relative clause, discourse relations, English as a foreign language

Submitted December 1 2017, accepted for publication March 112018

Corresponding author: Ema Živković

Faculty of Philosophy, University of Niš, Serbia

E-mail: e_zivkovic@yahoo.com 


\section{INTRODUCTION ${ }^{1}$}

Utterances in discourse can convey multiple propositions, some of which are recognized as more important than others. This observation has led to a distinction between at-issue and not-at-issue content. At-issue content conveys the speaker's main point and can be negotiated among discourse participants. On the other hand, not-at-issue content is in a way backgrounded with respect to the central message of the utterance. The notion of at-issueness has generated a lot of interest in recent literature (see, among others, AnderBois, Brasoveanu \& Henderson 2010; Jasinskaja 2016; Koev 2013; Murray 2014; Potts 2005; Simons, Tonhauser, Beaver \& Roberts 2010; Syrett \& Koev 2015).

Expressions which are typically considered to be not-at-issue are presuppositions, conventional and conversational implicatures. Non-restrictive relative clauses (henceforth NRRCs) have been categorized as conventional implicatures by Potts (2005) and as such, they have been treated as not-at-issue by other authors as well (Chierchia \& McConnellGinet 2000; Murray 2010). However, recent studies have challenged this view. For instance, an important observation is made by AnderBois et al. (2010), who point out that while sentence-medial NRRCs are not-at-issue, sentence-final NRRCs can convey atissue content. Syrett \& Koev (2015) provide empirical evidence for this observation. The results of their experiment can be interpreted within a discourse-based approach proposed by Jasinskaja (2016). Relying on the theories of processing hierarchical discourse units, she defines at-issueness as a dynamic notion and suggests that discourse relations influence the interpretation of the at-issue status of NRRCs. An important prediction that she makes is that NRRCs which enter into coordinating discourse relations with their main clauses, such as the underlined NRRC in (1), which is connected with the main clause via Narration, should receive more at-issue interpretations than NRRCs which enter into subordinating discourse relations with main clauses, as in (2), where the relation between the main clause and the NRRC is Elaboration.

(1) Kelly filed a lawsuit against her landlord Bob Simons, who then tried to bribe the judge.

(2) Kelly filed a lawsuit against her landlord Bob Simons, who owns several buildings in the city.

The prediction above was empirically confirmed in our earlier experiment with native speakers of English (Živković 2016). The experiment relied on the direct rejection test (Tonhauser 2012) to measure at-issueness of NRRCs in isolated sentences. It involved placing final NRRCs against main clauses as potential targets of direct rejections and manipulating discourse relations between main clauses and NRRCs. The obtained results represent the starting point of the present empirical study. Our main goals were to investigate the way Serbian students of English as a foreign language interpret the atissue status of English sentence-final NRRCs, as well as to compare the results to the existing data in English. The design of the experiment we conducted, together with the experimental stimuli, was taken from our study with English native speakers, and it will

\footnotetext{
${ }^{1}$ The data presented in this paper are part of the author's unpublished Master's thesis 'The at-issue status of non-restrictive relative clauses: A contrastive analysis of English and Serbian', Master's thesis, 2017, Faculty of Philosophy, University of Niš, Nišs
} 
be further described in section 3. To our knowledge, no theoretical or empirical studies so far have treated Serbian EFL students' interpretation of the at-issue status of any expressions. The current work, therefore, aims to fill this gap, as well as to provide further understanding of the relationship between discourse relations and at-issueness.

The paper is structured as follows: Section 2 defines the notion of at-issueness and reviews the discourse-based approach to the at-issue status of NRRCs. Section 3 elaborates on the conducted experiment and provides details on the participants, stimuli, and procedure. In section 4, the results obtained through the statistical analysis of the data are presented and discussed in relation to the initial goals of the study. The concluding section gives an overview of the study together with some suggestions for further research.

\section{THEORETICAL BACKGROUND}

\subsection{At-issue status of NRRCs}

In this paper, we rely on Simons et al. (2010) in defining at-issue status. They make a distinction between at-issue and not-at-issue content based on the ability to address the Question Under Discussion (henceforth QUD). Following Roberts (1996), they define the QUD as a semantic question which corresponds to the current discourse topic. It can be an actual question that has been asked or it may be given implicitly in the discourse. According to Simons et al., at-issue content directly addresses the QUD and expresses the main point of the utterance, while not-at-issue content cannot directly address the QUD and it expresses a secondary point.

One of the principal properties of at-issue content is that it is susceptible to direct rejections. In other words, at-issue content can be targeted by the markers of direct rejections such as 'No...' or 'That's not true'. On the other hand, not-at-issue content cannot be directly rejected ${ }^{1}$. For this reason, the direct rejection test is often applied for diagnosing the at-issue status of the semantic content which is conveyed by a range of expressions such as presuppositions (Chierchia \& McConnell-Ginet 2000; Xue \& Onea 2011), appositive constructions (AnderBois et al. 2010; Syrett \& Koev 2015), epistemic modals (von Fintel \& Gillies 2007; Papafragou 2006), and evidential markers (Faller 2002; Koev 2011; Murray 2010).

To determine the at-issue status of NRRCs, we can apply the test. In example (3), taken from Syrett \& Koev (2015), B's rejection does not seem to target the NRRC felicitously, suggesting that the NRRC is not-at-issue. However, AnderBois et al. (2010) observe that while sentence-medial NRRCs are always interpreted as not-at-issue, sentence-final NRRCs can sometimes acquire at-issue status. For instance, the direct rejection in example (4) felicitously targets the final NRRC. Therefore, AnderBois et al. conclude that the at-issue

\footnotetext{
${ }^{1}$ Although not-at-issue content cannot be directly rejected, it can be a target of indirect rejections. It is often diagnosed by using the 'Hey, wait a minute!' test (von Fintel 2004). 'Hey, wait a minute...' is a response which felicitously challenges not-at-issue content, but is an infelicitous response to an assertion. For instance, in (i) taken from von Fintel (2004), B's response can only target the presupposition that a mathematician proved Goldbach's Conjecture, but not the assertion that the mathematician was a woman.

(i) A: The mathematician who proved Goldbach's Conjecture is a woman.

B1: Hey, wait a minute. I had no idea that someone proved Goldbach's Conjecture.

B2: \# Hey, wait a minute. I had no idea that that was a woman.
} 
status of NRRCs may depend on the order in which assertions are introduced and interpreted in discourse.

(3) A: My friend Sophie, who is a classical violinist, performed a piece by Mozart. B: \# That's not true. She is a pianist.

(4) A: I introduced him to my friend Sophie, who is a classical violinist. B: That's not true. She is a pianist.

\subsection{Discourse-based approach}

The observation that final NRRCs can acquire at-issue status can be accounted for within a discourse-based approach proposed by Jasinskaja (2016), who relies on the main principles of discourse structure in defining at-issueness as a discourse-based notion. She starts with the assumption that discourse has an organization beyond the level of a sentence and discourse units play certain semantically and pragmatically important roles relative to other units. Discourse units are connected via discourse relations (for an overview of discourse relations see Asher \& Lascarides 2003; Halliday \& Hasan 1976; Jasinskaja \& Karagjosova 2016; Kehler 2002; Mann \& Thompson 1988; Zeevat 2011). Two main types of discourse relations are: coordinating relations (such as Narration and Contrast) and subordinating relations (such as Explanation and Elaboration).

The way discourse units connect to each other is regulated by global constraints on the development of discourse structure. One such constraint is the Right Frontier Constraint (Polanyi 1988; Webber 1991), which assumes that the discourse structure graph is constructed from left to right. Subordinating discourse relations, which create hierarchical structures and do not push the discourse forward, extend the vertical dimension of the graph. On the other hand, coordinating relations, which contribute to discourse progression in a left-to-right manner, extend the structure horizontally. According to the Right Frontier Constraint, a new unit can attach only to a node along the right frontier of a discourse graph, which consists of the last (rightmost) processed node and all the nodes to which it is connected via a subordinating relation.

Jasinskaja shows that the approach to discourse structure described above can be applied to the analysis of the at-issue status of NRRCs. She first assumes that NRRCs represent independent discourse units which address their own QUDs and can participate in discourse relations with other units such as main clauses. Jasinskaja observes that NRRCs typically connect with their main clauses via subordinating discourse relations. The example below illustrates a main clause, which addresses the QUD What happened?, and a sentence-final discourse-structurally subordinate NRRC, which addresses the QUD Who is Chloe?.

(5) 'All Stars' has chosen to audition Chloe, who is the girl you met in the gym yesterday.

Figure 1 illustrates the discourse structure for (5). The NRRC provides additional information about one of the entities of the main clause, so the discourse relation in this example can be classified as Elaboration. Since this is a subordinating relation, it expands the vertical dimension of the discourse graph, so both the main clause node and the NRRC node will remain on the right frontier and be open for further attachment of new discourse material, such as a direct rejection. This means that, in principle, the direct rejection in (6) below can be understood as referring to either the main clause or the NRRC. Therefore, it is predicted that either the main clause or the NRRC can be at-issue. 


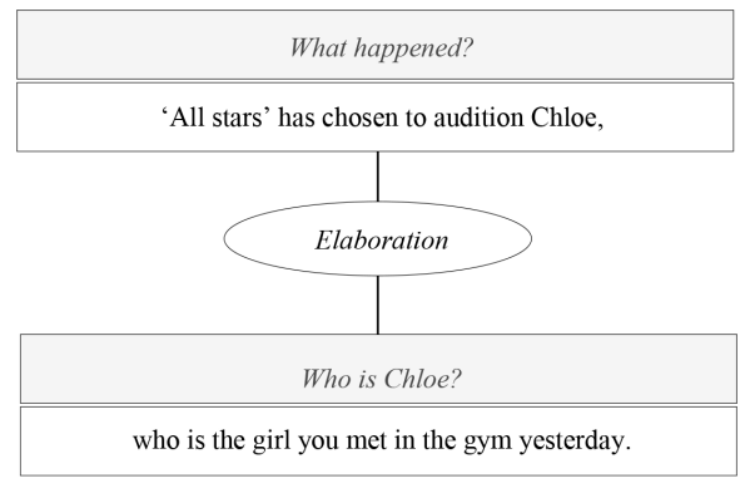

Fig. 1 Discourse structure for (5)

(6) A: 'All Stars' has chosen to audition Chloe, who is the girl you met in the gym yesterday.

B: That's not true.

While NRRCs typically connect with their main clauses via subordinating discourse relations, they can also enter into coordinating relations with their main clauses. Holler (2008) argues that a particular type of NRRCs known as the continuative relative clause (henceforth CRC) participates in coordinating discourse relations with the main clause. The existence of CRCs has been recorded by many other authors (Cornilescu 1981; Depraetere 1996; Jespersen 1970; Koev 2013; Loock 2007). It has often been defined as a type of NRRC which enables a forward movement of reference time within the narrative. In this study, however, we rely on Holler in defining the CRC. Holler makes a distinction between appositive and continuative NRRCs ${ }^{2}$ based on the way they connect to their main clauses in discourse. While both appositive relative clauses (henceforth ARCs) and CRCs are subordinate clauses in syntactic terms, ARCs enter into subordinating discourse relations, whereas CRCs enter into coordinating discourse relations with the main clause.

In order to account for the at-issue status of CRCs, Jasinskaja turns to the Right Frontier Constraint. In (7), the underlined CRC describes an event which takes place after the main clause event, so the relation between the clauses is Narration, lexically indicated by then in the CRC. As illustrated in Figure 2, the node corresponding to the CRC is on the right frontier, together with the discourse topic node corresponding to the whole sentence, represented by the overarching QUD What happened?. Since the relation between the main clause and the CRC is coordination, the main clause node is closed off by the following CRC and is not on the right frontier. Therefore, a subsequent unit, such as the direct rejection in (7), can attach either to the CRC or to the sentence as a whole, but not to the main clause. This means that only the CRC content can be at-issue by the end of processing the sentence.

\footnotetext{
${ }^{2}$ Loock (2007) and Jasinskaja (2016) use the term appositive relative clause (ARC) as a synonym for nonrestrictive relative clause, and see the $\mathrm{CRC}$ as a subtype of ARC. On the other hand, according to Holler (2008) CRCs and ARCs are mutually exclusive subclasses of NRRC, which is the terminology we adopted in this paper.
} 
(7) A: Oscar met a farmer, whom he then asked the way. B: That's not true.

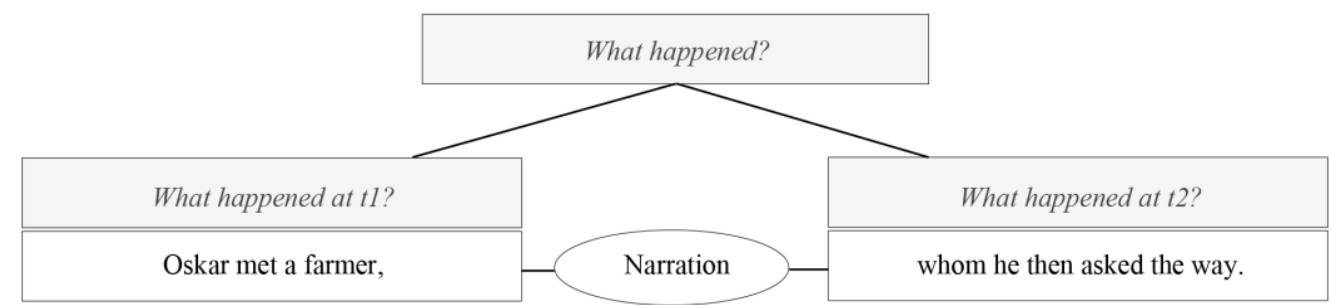

Fig. 2 Discourse structure for (7)

To summarize, Jasinskaja's approach predicts that the interpretation of the at-issue status of sentence-final NRRCs depends on the type of discourse relation between the main clause and the NRRC. When it comes to subordinating discourse relations, either the ARC or the main clause content can be at-issue. On the other hand, in the case of coordinating relations, only the CRC content can be at-issue. An important prediction that follows from this approach is that final CRCs should behave more at-issue than final ARCs in an experimental setting.

This prediction was tested in an earlier empirical study which involved native speakers of English (Živković 2016). The test items in the experiment consisted of a main clause and a sentence-final NRRC. The participants were given a forced choice between the rejection of the main clause and the rejection of the NRRC. The experiment manipulated coordinating and subordinating discourse relations between main clauses and NRRCs in the test items. The results of the experiment confirmed that Jasinskaja's approach made the correct prediction with regard to the role of discourse relations in the interpretation of the at-issue status of ARCs and CRCs, given that the percentage of CRC rejections was significantly higher than the percentage of ARC rejections. These results were taken as the starting point of our empirical research, which we elaborate on in the following section.

\section{METHODOLOGY OF THE RESEARCH}

The main goals of this study were to present new experimental evidence regarding the way Serbian speakers interpret the at-issue status of sentence-final NRRCs in English as a foreign language, as well as to compare the obtained results to the existing data in English. Assuming that at-issue status is universally represented in different languages, we expect to find no differences in the at-issue status of NRRCs in English and Serbian. Therefore, we predicted that Serbian students would interpret final CRCs as expressing more at-issue behavior than final ARCs in English and that their responses would be similar to those of English native speakers. In other words, we expected the results of the present experiment and the results of the English experiment to match to a great extent.

The participants of the experiment were 34 undergraduate Serbian students of the English Department at the Faculty of Philosophy, University of Niš. The age of the participants ranged between 19 and 25 . The participants were randomly assigned to one 
of the four lists of test items, described in further detail below. They were roughly evenly distributed among the lists: one list had 10 participants, and the other three had 8 participants each.

Since the aim of the experiment was to compare the results with the ones obtained in the English experiment (Živković 2016), the questionnaires were taken from that study. The stimuli consisted of isolated sentences composed of a main clause and a sentence-final NRRC - either an ARC or a CRC. Each sentence was followed by two responses: a direct rejection of the main clause and a direct rejection of the NRRC. The participants were presented with a forced-choice task, where they had to choose one of the two possible responses. Assuming that only at-issue content can be targeted by direct rejections, the participants' decision to choose the direct rejection targeting the NRRC over the direct rejection targeting the main clause was taken as strong evidence that the NRRC expressed at-issue content.

In each test sentence, the nominal anchor for the NRRC was the object of the main clause. The main clause and the NRRC of each sentence differed with respect to the number or gender marking on the subject, as in (8) and (9). Therefore, the participants could clearly understand which clause was being targeted by each direct rejection.

(8) The symphony directors hired my friend Sophie, who then had an argument with the principal conductor.
a. No, they didn't.
b. No, she didn't.
(target: main clause)
(target: NRRC)

(9) Officer James Wilson arrested Lisa, who broke out of jail two days later.
a. No, he didn't.
(target: main clause)
b. No, she didn't.
(target: NRRC)

The test items involved the manipulation of four types of discourse relations between main clauses and NRRCs: two coordinating ones (Narration and Contrast) and two subordinating ones (Explanation and Elaboration). In each set of test items, the main clause remained the same, while the NRRC changed depending on the type of discourse relation between the clauses. An example set is given in Table 1.

Table 1 Example of a set of test items

\begin{tabular}{ll}
\hline Type of discourse relation & Sentence with the NRRC underlined \\
\hline 1. Narration & $\begin{array}{l}\text { In her will, Bethany left her fortune to Sam, who then used the } \\
\text { money to start his own business. }\end{array}$ \\
2. Contrast & $\begin{array}{l}\text { In her will, Bethany left her fortune to Sam, who, however, } \\
\text { gambled it all away. }\end{array}$ \\
3. Explanation & $\begin{array}{l}\text { In her will, Bethany left her fortune to Sam, who took care of } \\
\text { her for years. }\end{array}$ \\
4. Elaboration & $\begin{array}{l}\text { In her will, Bethany left her fortune to Sam, who was one of } \\
\text { her many nephews. }\end{array}$ \\
\hline
\end{tabular}

There were 16 sets of sentences such as the one in Table 1, generating 64 test items in total. The test items were distributed among four lists in a Latin square fashion so that each list contained 16 test sentences, which means that each participant could see only one sentence from each set. The test items were presented together with 18 fillers in a randomized order. All stimuli are included in the Appendix. 
The filler items were constructed to distract the participants from the goal of the experiment. They resembled the test items in form. Each filler was followed by two responses, as in (10). One response was appropriate and it targeted either the main clause or the NRRC, while the other one was nonsensical in the given context because it could target neither of the two clauses. The participants who chose the nonsensical answer to two or more fillers were disqualified from the experiment due to the possibility that they were not completely focused on the task ( 2 additional participants).

(10) Sandra sent a wedding invitation to Ryan, who, however, declined to come.
a. No, she won't.
(nonsensical)
b. No, he didn't.
(appropriate)

The experiment was administered in the form of an online survey ${ }^{3}$. Before proceeding to the task, the participants were asked to read the instructions, where they were told that they would read short statements followed by two responses. Their task consisted in choosing the appropriate response for each statement. In case both responses seemed appropriate, they were instructed to choose the one which sounded more natural to them. The gathered data were submitted for statistical analysis.

\section{RESULTS AND DISCUSSION}

The data were analyzed in $\mathrm{R}$ ( $\mathrm{R}$ Core Team, 2013), an open source programming language for statistical computing. We started the analysis by calculating the percentage of NRRC direct rejections with respect to the discourse relation between the main and the NRRC. The results are illustrated in Figure 3. When the relation between the clauses was subordination, the participants opted for ARC rejection $41.2 \%$ of the time, while the main clause was rejected $58.8 \%$ of the time. On the other hand, when the relation between the clauses was coordination, the participants chose to reject the $\mathrm{CRC}$ as much as $76.5 \%$ of the time, whereas the percentage of main clause rejections was $23.5 \%$.

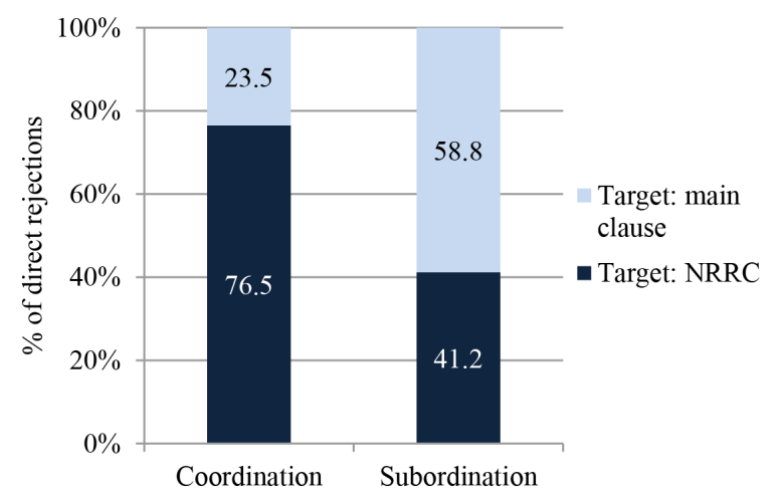

Fig. 3 Percentage of direct rejections targeting either the main clause or the CRC/ARC

\footnotetext{
${ }^{3}$ The survey was generated and administered using Google Forms, available at https://www.google.com/forms/about/.
} 
To explore the association between the type of discourse relation and the participants' responses, we conducted a chi-square test for independence (with Yates Continuity Correction). The dependent variable was the percentage of direct rejections chosen for each clause type. The independent variable was the type of relation between the main clause and the NRRC. The results showed that there was a significant association between these variables: $X^{2}(1,544)=68.49, p<.001^{4}$. This means that whether the participants perceived the NRRC or the main clause as conveying at-issue content depended on whether the two clauses were connected by a subordinating or a coordinating relation. In the greatest majority of cases, CRCs were interpreted as at-issue when compared to main clauses. This is in line with the discourse-based approach, according to which the final CRC should be atissue and open for further attachment, while the main clause cannot be made at-issue anymore. On the other hand, in the case of ARCs, either the main clause or the ARC can adopt at-issue status, so it is expected that ARCs would do so roughly half of the time. The results again fit the outlined approach.

If we compare these results to the ones obtained in the English experiment, we notice that the numbers are very similar. Table 2 shows that the percentage of direct rejections targeting the CRCs in our experiment was $76.5 \%$, while in the English experiment the percentage of CRC rejections was $73.1 \%$. When it comes to subordinating relations, Serbian EFL students opted for the ARC rejection instead of the main clause rejection in $41.2 \%$ of the cases, while native speakers chose the ARC direct rejection in $47.5 \%$ of the cases. Therefore, the results suggest that Serbian EFL students were able to interpret the at-issue status of NRRCs at the level of native speakers.

Table 2 Percentage of CRC/ARC rejections in the present study and Živković (2016)

\begin{tabular}{lcc}
\hline & $\begin{array}{c}\text { Experiment with Serbian } \\
\text { EFL students } \\
\text { (present study) }\end{array}$ & $\begin{array}{c}\text { Experiment with native } \\
\text { speakers of English } \\
\text { (Živković 2016) }\end{array}$ \\
\hline Percentage of CRC rejections & $76.5 \%$ & $73.1 \%$. \\
Percentage of ARC rejections & $41.2 \%$ & $47.5 \%$ \\
\hline
\end{tabular}

To provide further support for the conclusion above, we calculated the percentage of $\mathrm{CRC}$ and ARC rejections based on the specific type of coordinating and subordinating relations between NRRCs and main clauses. The results are shown in Figure 4. In the case of Narration, the participants showed a preference for CRC rejections (73.5\%) over main clause rejections. A slightly stronger preference for CRC rejections is observed when it comes to Contrast - 79.4\% of CRC rejections. A chi-square test for independence showed no significant association between the participants' responses and the type of coordinating relation between the main clause and the CRC: $X^{2}(1,272)=1.01, p=.317$.

The analysis was repeated for the two groups of ARCs. When it comes to Explanation, ARCs were targeted by $41.9 \%$ of rejections. Similar results were obtained when the relation between the clauses was Elaboration - $40.4 \%$ of ARC rejections. Again, a chi-square test for independence showed there was no significant difference in the participants' responses

${ }^{4}$ Statistical significance is achieved for $p<.05$. 
based on the specific type of subordinating relation between the clauses: $X^{2}(1,272)=0.01$, $p=.902$.

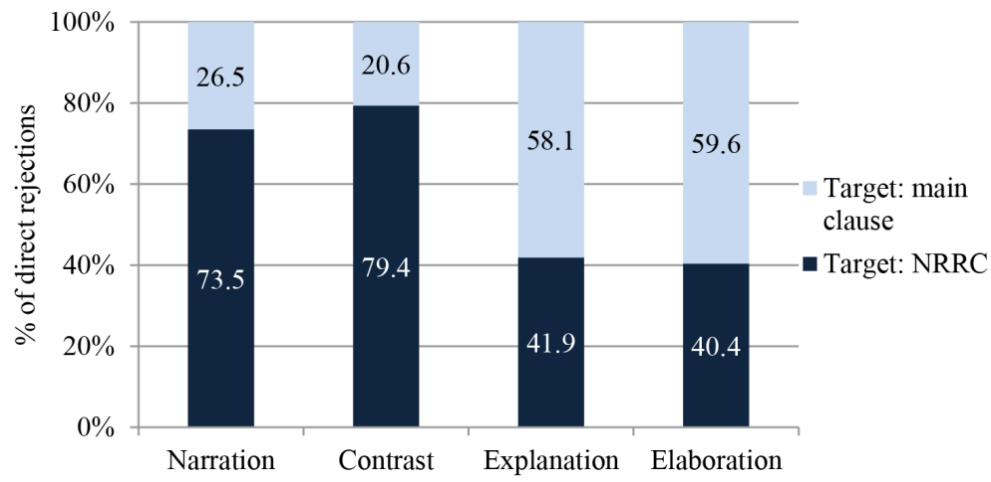

Fig. 4 Percentage of main clause and NRRC rejections depending on the specific type of discourse relations

As shown in Table 3, the presented results are similar to the ones obtained in the English experiment for all four conditions, though we can notice that the percentage of CRC rejections in the case of Contrast was slightly higher for Serbian EFL students $(79.4 \%)$ than for native speakers of English $(70.8 \%)$. This difference, however, was not significant: $X^{2}(1,372)=2.91, p=.088$. A slight difference is also noticed when it comes to the ARCs connected with the main clauses via Explanation. Namely, the percentage of ARC rejections was slightly lower in the present experiment than in the English experiment $-41.9 \%$ vs. $51.3 \%$, respectively. Again, the statistical analysis did not show that this difference was significant: $X^{2}(1,372)=2.66, p=.103$.

Table 3 Percentage of NRRC rejections depending on the specific type of discourse relations in the present study and Živković (2016)

\begin{tabular}{lccc}
\hline & & $\begin{array}{c}\text { Experiment with Serbian } \\
\text { EFL students } \\
\text { (present study) }\end{array}$ & $\begin{array}{c}\text { Experiment with native } \\
\text { speakers of English } \\
\text { (Živković 2016) }\end{array}$ \\
\hline $\begin{array}{l}\text { Percentage of CRC } \\
\text { rejections }\end{array}$ & Narration & $73.5 \%$ & $75.4 \%$ \\
\hline Percentage of ARC & Explanation & $79.4 \%$ & $70.8 \%$ \\
rejections & Elaboration & $40.4 \%$ & $51.3 \%$ \\
\hline
\end{tabular}

We can conclude that our initial prediction that the results of both experiments would largely coincide proved to be a correct one. In both experiments the participants chose the NRRC rejection more frequently when the discourse relation between the NRRC and the main clause was coordinating than when the relation was subordinating. A detailed analysis revealed that in both experiments there was a significant association between the 
participants' responses and the type of discourse relation (coordination and subordination) between the two clauses. In other words, Serbian EFL students interpreted CRCs as expressing more at-issue behavior than ARCs, just like native speakers of English. Given these results, it can be concluded that their performance at the syntax-discourse interface regarding this phenomenon can qualify as nativelike. This conclusion is further supported by the fact that the results of both experiments showed that CRCs were almost equally open to further attachments regardless of the specific type of coordinating relation between the main clause and the CRC. The same observation holds for the ARC and the two types of subordinating relations.

\section{CONCLUSION}

Building on prior work, the present paper sought to enrich our understanding of the possible ways in which content expressed by English NRRCs is interpreted as at-issue by Serbian EFL students. The conducted experiment was based on the prediction that final CRCs should express more at-issue behavior than final ARCs (Jasinskaja 2016) and it involved placing sentence-final CRCs/ARCs against main clauses as potential targets for direct rejections. This kind of design was guided by the assumption that only at-issue content can be targeted by direct rejections. The participants were Serbian undergraduate students of English at the Faculty of Philosophy in Niš. We started with the assumption that there were no differences in the at-issue status of NRRCs in English and Serbian. Based on this, we further predicted that the results of the present experiment would be similar to the ones obtained in the experiment with native speakers of English (Živković 2016). The experiment we conducted confirmed our initial prediction. As expected, the percentage of CRC rejections was much higher than the percentage of ARC rejections ( $76.5 \%$ vs. $41.2 \%$, respectively). The results indicated that the participants' willingness to choose the NRRC over the main clause as the target of the subsequent rejection depended on whether the clauses were connected via coordinating or subordinating discourse relations. Therefore, we can conclude that Serbian EFL students were able to interpret the at-issue status of English NRRCs in the same way as native speakers.

It is important to point out that we started with the assumption that there were no differences in the at-issue behavior of English and Serbian NRRCs. Given the fact that there have been no studies dealing with the at-issue status of any meaning types in Serbian so far, the next step could involve investigating Serbian NRRCs in this respect and comparing them to English NRRCs. The results would reveal if it is useful to additionally investigate the effects of duration of studies or linguistic competence on EFL learners' interpretation of at-issueness and they would further enable us to explore potential L1 transfer effects regarding this phenomenon.

Finally, we hope that the present study will inspire future empirical research involving the interpretation of at-issue status in a foreign language. So far, at-issueness investigations have involved native speakers of English almost exclusively, so we have little idea of whether the same observations apply cross-linguistically, and how different categories of meaning will be interpreted with respect to at-issueness in a foreign language. Therefore, the present paper can help build a foundation for future research on at-issue meanings not only in English as a foreign language but in other languages as well. 


\section{REFERENCES}

AnderBois, S., Brasoveanu, A. \& Henderson, R., (2010), "Crossing the appositive-at-issue meaning boundary", Semantics and Linguistic Theory 20: pp. 328-346.

Asher, N. \& Lascarides, A., (2003), Logics of Conversation, Cambridge University Press, Cambridge.

Chierchia, G. \& McConnell-Ginet, S., (2000), Meaning and Grammar: An Introduction to Semantics, MIT Press, Cambridge.

Cornilescu, A., (1981), "Non-restrictive relative clauses: An essay in semantic description", Revue Roumaine de Linguistique 26: pp. 41-67.

Depraetere, I., (1996), "Foregrounding in English relative clauses", Linguistics 34: pp. 699-731.

Faller, M., (2002), Semantics and Pragmatics of Evidentials in Cuzco Quechua, Doctoral dissertation, Stanford University, Stanford.

von Fintel, K., (2004), "Would you believe it? The king of France is back! (Presuppositions and truth-value intuitions) ", In: Bezuidenhout, A. \& Reimer, M. (eds.) Descriptions and Beyond (pp. 315-341), Oxford University Press, Oxford.

von Fintel, K. \& Gillies, A., (2007), "An opinionated guide to epistemic modality", In: Gendler, T. S. \& Hawthorne, J. (eds.) Oxford Studies in Epistemology, Vol. 2 (pp. 32-62), Oxford University Press, Oxford.

Halliday, M. A. K. \& Hasan, R., (1976), Cohesion in English, Longman, London.

Holler, A., (2008), "A discourse-relational approach to continuation", In: Benz, A. \& Kühnlein, P. (eds.) Constraints in Discourse (pp. 249-266), John Benjamins Publishing Company, Amsterdam.

Jasinskaja, K., (2016), Not at issue any more, Ms. available at http://dslc.phil-fak.unikoeln.de/sites/dslc/katja_files/jasinskaja_any_more.pdf

Jasinskaja, K. \& Karagjosova, E., (2016), Rhetorical Relations, Ms. available at http://dslc.phil-fak.unikoeln.de/sites/dslc/katja_files/Jasinskaja_Karagjosova_RR.pdf

Jespersen, O., (1970), A Modern English Grammar on Historical Principles (Vol. 3), George Allen \& Unwin LTD, London.

Kehler, A., (2002), Coherence, Reference, and the Theory of Grammar, CSLI, Stanford.

Koev, T., (2011), "Evidentiality and temporal distance learning", Semantics and Linguistic Theory 21: pp. 115134.

Koev, T., (2013), Apposition and the Structure of Discourse, Doctoral dissertation, Rutgers University, New Brunswick.

Loock, R., (2007), "Appositive relative clauses and their functions in discourse", Journal of pragmatics 39, Vol. 2: pp. 336-362.

Mann, W. C. \& Thompson, S., (1988), "Rhetorical Structure Theory: Toward a functional theory of text organization", Text \& Talk 8, Vol. 3: pp. 243-281.

Murray, S., (2010), Evidentiality and the Structure of Speech Acts, Doctoral dissertation, Rutgers University, New Brunswick.

Murray, S., (2014), "Varieties of update", Semantics \& Pragmatics 7, Vol. 2: pp. 1-53.

Papafragou, A., (2006), "Epistemic modality and truth conditions", Lingua 116: pp. 1688-1702.

Polanyi, L., (1988), "A formal model of the structure of discourse", Journal of Pragmatics 12: pp. 601-638.

Potts, C., (2005), The Logic of Conventional Implicatures, Oxford University Press, Oxford.

$\mathrm{R}$ Core Team, (2013), R: A language and environment for statistical computing, $\mathrm{R}$ Foundation for Statistical Computing, Vienna, Retrieved from http://www.R-project.org

Roberts, C., (1996), "Information structure: Towards an integrated formal theory of pragmatics", In: Yoon, J. H. \& Kathol, A. (eds.) OSU Working Papers in Linguistics 49: Papers in Semantics (pp. 91-136), The Ohio State University Department of Linguistics, Ohio.

Simons, M., Tonhauser, J., Beaver, D. \& Roberts, C., (2010), "What projects and why", Semantics and Linguistic Theory 20: pp. 309-327.

Syrett, K. \& Koev, T., (2015), "Experimental evidence for the truth conditional contribution and shifting information status of appositives", Journal of Semantics 32, Vol. 3: pp. 525-577.

Tonhauser, J., (2012), "Diagnosing (not-)at-issue content", Semantics of Under-Represented Languages of the Americas 6: pp. 239-254.

Webber, B. L., (1991), "Structure and ostension in the interpretation of discourse deixis", Natural Language and Cognitive Processes 2, Vol. 6: pp. 107-135.

Xue, J. \& Onea, E., (2011), "Correlation between presupposition projection and at-issueness: An empirical study", In: Roberts, C., Tonhauser, J. \& Kierstead, G. (eds.) Proceedings of the ESSLLI 2011 Workshop on Projective Meaning, Ljubljana.

Zeevat, H., (2011), "Rhetorical relations", In: Maienborn, C., Von Heusinger, K. \& Portner, P. (eds.) Semantics: An International Handbook of Natural Language and Meaning (pp. 946-970), De Gruyter Mouton, Boston. 
Živković, E., (2016), 'The at-issue status of appositive relative clauses: Evidence for a discourse-based approach', Master's thesis, Universitat Pompeu Fabra, Barcelona.

Živković, E., (2017), 'The at-issue status of non-restrictive relative clauses: A contrastive analysis of English and Serbian', Master's thesis, Faculty of Philosophy, University of Niš, Niš.

\section{APPENDIX}

\section{Test items}

Below are presented 16 sets of test items taken from Živković (2016). Each sentence in a set underwent four modifications for the purpose of manipulating four types of discourse relations. The manipulated coordinating relations were Narration (a) and Contrast (b), while the subordinating ones were Explanation (c) and Elaboration (d).

(1) a. This year, the Paris Literary Prize committee awarded the prize to Tessa Brown, who then gave the prize money to charity.

b. This year, the Paris Literary Prize committee awarded the prize to Tessa Brown, who, however, refused to accept it.

c. This year, the Paris Literary Prize committee awarded the prize to Tessa Brown, who wrote one of the greatest historical novels of the decade.

d. This year, the Paris Literary Prize committee awarded the prize to Tessa Brown, who is a first-time novelist.

(2) a. Officer James Wilson arrested Lisa, who broke out of jail two days later.

b. Officer James Wilson arrested Lisa, who was, however, released a week later.

c. Officer James Wilson arrested Lisa, who committed a felony.

d. Officer James Wilson arrested Lisa, who had already been in jail before.

(3)

a. Pam gave the book to Emil, who then took it to the library.

b. Pam gave the book to Emil, who, however, lost it the next day.

c. Pam gave the book to Emil, who needed it for his book club meeting.

d. Pam gave the book to Emil, who is the guy she met in the library.

(4) a. The judges gave a low score to last year's champion Michael Curry, who was then disqualified for arguing with them.

b. The judges gave a low score to last year's champion Michael Curry, who, however, fought his way to the top in the next tournament.

c. The judges gave a low score to last year's champion Michael Curry, who delivered one of the worst performances of his career.

$\mathrm{d}$. The judges gave a low score to last year's champion Michael Curry, who skated for the UK.

(5) a. Jack tried to kiss Monica, who then told her boyfriend about it.

b. Jack tried to kiss Monica, who, however, slapped him in the face.

c. Jack tried to kiss Monica, who has always been the love of his life.

d. Jack tried to kiss Monica, who is a girl from his class.

(6) a. The managers assigned the project to Mark, who finalized it three months later.

b. The managers assigned the project to Mark, who, however, failed to finish it before the deadline.

c. The managers assigned the project to Mark, who was the only experienced engineer at the meeting.

d. The managers assigned the project to Mark, who joined the team in March. 
(7) a. The spectators cheered on Stewart, who then retired a few weeks after the game.

b. The spectators cheered on Stewart, who, however, forfeited the match.

c. The spectators cheered on Stewart, who scored the winning point.

d. The spectators cheered on Stewart, who was the youngest player on the team.

(8) a. Sarah phoned Andrew, who then told her the truth.

b. Sarah phoned Andrew, who, however, hung up on her.

c. Sarah phoned Andrew, who owed her an explanation.

d. Sarah phoned Andrew, who is her ex-boyfriend.

(9) a. Kelly filed a lawsuit against her landlord Bob Simons, who then tried to bribe the judge.

b. Kelly filed a lawsuit against her landlord Bob Simons, who, however, fled the country a few days later.

c. Kelly filed a lawsuit against her landlord Bob Simons, who had evicted her without prior notice.

d. Kelly filed a lawsuit against her landlord Bob Simons, who owns several buildings in the city.

(10) a. The dance instructor showed the routine to her students, who then repeated it from beginning to end perfectly.

b. The dance instructor showed the routine to her students, who, however, forgot the steps by the next class.

c. The dance instructor showed the routine to her students, who were required to perform it at Michigan Dance Challenge.

d. The dance instructor showed the routine to her students, who were all beginners.

(11) a. Tom bought an expensive necklace for Laura, who wore it at the party the next day.

b. Tom bought an expensive necklace for Laura, who, however, exchanged it for a bracelet.

c. Tom bought an expensive necklace for Laura, who was celebrating her 30th birthday.

d. Tom bought an expensive necklace for Laura, who enjoys wearing jewelry.

(12) a. The symphony directors hired my friend Sophie, who then had an argument with the principal conductor.

b. The symphony directors hired my friend Sophie, who, however, turned out to be a horrible violinist.

c. The symphony directors hired my friend Sophie, who was the best violinist at the audition.

d. The symphony directors hired my friend Sophie, who is a classical violinist. (taken from Syrett \& Koev 2015)

(13) a. Last Thursday, Philip proposed to Julie, who then disappeared the next morning.

b. Last Thursday, Philip proposed to Julie, who, however, turned him down.

c. Last Thursday, Philip proposed to Julie, who had been his girlfriend for seven years.

d. Last Thursday, Philip proposed to Julie, who works with him in the office.

(14) a. Dr. Nick Richards gave a lollipop to Chloe, who then asked for another one.

b. Dr. Nick Richards gave a lollipop to Chloe, who, however, continued crying.

c. Dr. Nick Richards gave a lollipop to Chloe, who had behaved well during the exam. 
(15) a. At the meeting, George publically supported his wife, who was then hired by another company.

b. At the meeting, George publically supported his wife, who, however, lost the elections.

c. At the meeting, George publically supported his wife, who was running for office.

d. At the meeting, George publically supported his wife, who is a proud New

Yorker.

(16) a. In her will, Bethany left her fortune to Sam, who then used the money to start his own business.

b. In her will, Bethany left her fortune to Sam, who, however, gambled it all away.

c. In her will, Bethany left her fortune to Sam, who took care of her for years.

d. In her will, Bethany left her fortune to Sam, who was one of her many nephews.

\section{Filler items}

Below is presented a full set of fillers included in the experiment.

(17) Last night Ruth had a fight with her husband, who then moved out of the house.

(18) The nurses had a meeting with executive director John Stocks, who then promised to raise their salaries.

(19) Yesterday, Steve ran into Tina, who then offered him a ride home.

(20) Sandra sent a wedding invitation to Ryan, who, however, declined to come.

(21) Ashley fell in love with an Italian guy, who, however, married another woman.

(22) Hugh apologized to his parents, who, however, decided to punish him anyway.

(23) Principal Michael Brown fired Mrs. Robinson, who was constantly late for work.

(24) Carter organized a fundraiser for the Greys, who recently lost their home in a fire.

(25) Linda shared her secret with Bill, who is a very trustworthy person.

(26) Martin took a photo with Lilly Watson, who is a famous R\&B singer.

(27) Top universities were recruiting Bruce, who was a senior in high school. (taken from Syrett \& Koev 2015)

(28) Last night, Stella Atkins had dinner with Josh Bradley, who is the producer of her new movie.

(29) Harley watched a horror movie with Hope, who then had nightmares all night.

(30) Hank read a story to his daughter, who then fell asleep in his arms.

(31) Everyone bet on Russell Sheppard, who was, however, defeated by his opponent.

(32) My sisters went camping with Phoebe, who got bitten by a snake.

(33) Last week, Norman threw a party for Samantha, who finally decided to retire.

(34) The inspectors interrogated Paul Randall, who was a suspect in a murder case. 


\section{INTERPRETACIJA INFORMACIJSKE AKTUELNOSTI NERESTRIKTIVNIH RELATIVNIH KLAUZA KOD SRPSKIH STUDENATA ENGLESKOG JEZIKA}

Sadržaj kojim se iskazuje najbitnija informacija informacijski je aktuelan, dok je sadržaj koji je na neki način u pozadini u odnosu na glavnu poruku informacijski neaktuelan. Ovaj rad doprinosi istraživanju izraza koji su u diskursu uglavnom informacijski neaktuelni jer se bavi interpretacijom informacijske aktuelnosti nerestriktivnih relativnih klauza (NRK) u engleskom jeziku kao stranom. Rad polazi od pristupa informacijskoj aktuelnosti Jasinskaje (Jasinskaja 2016), koji se oslanja na opšta pravila teorija o hijerarhijskoj strukturi diskursa. Jedna od mnogobrojnih hipoteza ovakvog pristupa jeste da bi u eksperimentalnim uslovima znatno veći broj finalnih NRK koje su nezavisne u logičkosemantičkom smislu, odnosno koje sa glavnom klauzom ostvaruju nezavisni diskursni odnos, bio informacijski aktuelan u poređenju sa brojem finalnih NRK koje sa glavnom klauzom stoje u zavisnom diskursnom odnosu. Ova hipoteza je u engleskom jeziku empirijski potvrđena u Živković (2016). Oslanjajući se na pomenute studije, cilj ovog rada je da utvrdi na koji način srpski studenti engleskog jezika $i$ književnosti intepretiraju informacijski status NRK, kao $i$ da uporedi rezultate sa rezultatima dobijenim u engleskom jeziku. U eksperimentu smo koristili test direktne negacije (Tonhauser 2012) radi utvrđivanja informacijske aktuelnosti finalnih NRK. Rezultati dobijeni statističkom analizom pokazali su da su ispitanici davali slične odgovore kao izvorni govornici engleskog jezika, odnosno da su u značajno većem broju slučajeva birali negaciju nezavisnih NRK. Stoga se može zaključiti da su studenti engleskog jezika interpretirali informacijsku aktuelnost finalnih NRK na sličan način kao izvorni govornici engleskog.

Ključne reči: informacijska (ne)aktuelnost, nerestriktivna relativna klauza, apozitivna relativna klauza, kontinuativna relativna klauza, diskursni odnosi, engleski jezik kao strani 